\title{
Plasma Levels of Insulin-Like Growth Factor-I Are Reduced at One Week of Age in Monosodium L-Glutamate-Treated Mice
}

\author{
Toru YAMAMOTO, Satoshi MATSUO, Yasuo UESHIMA, \\ Fumio INOUE, AKIHIKo KINUGASA aNd TADASHI SAWADA \\ Department of Pediatrics, Kyoto Prefectural University of \\ Medicine, Kyoto 602, Japan
}

\begin{abstract}
Administration of monosodium L-glutamate (MSG) to neonatal mice produces a hypothalamic syndrome consisting of stunted growth and later development of obesity. We assayed plasma insulin (IRI), thyroxine (T4) and insulin-like growth factor-I (IGF-I) to investigate their roles in the growth of the mice. Two $\mathrm{mg} / \mathrm{g}$ body weight of MSG was injected into newborn male mice daily for five successive days after birth. Plasma IRI levels were increased on and after 8 weeks of age in MSG-treated mice. There was no significant difference between the plasma T4 levels in MSG-treated mice and those in controls at any age studied. In contrast to this, plasma IGF-I levels in MSG-treated mice were reduced at one week and after. These results suggest that a decreased plasma IGF-I level contributes to the retarded linear growth which develops soon after the administration of MSG, and hyperinsulinemia contributes to the later development of obesity in MSG-treated mice.
\end{abstract}

Key words: IGF-I, MSG-treated mice.

(Endocrine Journal 40: 461-465, 1993)

IT IS KNOWN that the administration of monosodium L-glutamate (MSG) to neonatal mice produces hypothalamic injury including necrosis of the arcuate nucleus and ventral two-thirds of ventromedial nucleus $[1,2]$. This injury results in several neuroendocrinological aberrations in MSG-treated mice [3], which subsequently result in typical physical characteristics such as stunted growth which develops soon after MSG-treatment and obesity which usually develops after 8 weeks. To investigate the effects of peripheral hormones on these characteristics, we determined plasma insulin (IRI), thyroxine (T4) and insulin-like growth factor-I (IGF-I) during the developmental period in MSG-treated mice.

Received: November 2, 1992

Accepted: April 16, 1993

Correspondence to: Dr. Toru YAMAMOTO, Department of Pediatrics, Kyoto Prefectural University of Medicine, 465 Kajii-cho, Hirokoji, Kawaramachi, Kamikyo-ku, Kyoto 602, Japan

\section{Materials and Methods}

Jcl-ICR strain mice were purchaced from Nihon Clea (Osaka). The mice were maintained with food (CE-2, Nihon Clea, Osaka) and tap water, ad libitum. The room temperature was constantly maintained at $23^{\circ} \mathrm{C}$, and the light was kept on from $600 \mathrm{~h}$ to $1800 \mathrm{~h}$. Ten percent of MSG (Nacalai Tesque, Kyoto) solution ( $2 \mathrm{mg} / \mathrm{g}$ of body weight) was subcutaneously injected into newborn male mice daily for five successive days after birth [2]. Male mice injected with $0.15 \mathrm{M}$ solution of sodium chloride in a similar way were used as controls. Both groups were suckled by mothers and weaned at 3 weeks after birth.

Body weight, nasoanal length and tail length in MSG-treated mice and controls were measured at $4,8,12,20$ weeks of age. The Lee index was calculated from the body weight and nasoanal length [4]. The number of animals in each group was 18 to 22 . 
Mice at 4, 8, 12, 20 weeks of age fed ad libitum were decapitated, and their blood samples were collected in heparinized tubes and centrifuged immediately to obtain plasma. Plasma IRI and T4 levels were determined by enzyme immunoassay, using Insulin B-test (Wako Pure Chemical Industry, Osaka) and Enzymun Test T4 (Boehringer Mannheim, Mannheim), respectively. At 1, 2, 4, 8, 12 and 20 weeks of age, plasma samples were also obtained with EDTA dipotassium salt instead of heparin to measure plasma IGF-I by radioimmunoassay by the double antibody method (Somatomedin-C, Nichols Institute Diagnostics, San Juan Capistrano, CA), after extraction with acid ethanol [5]. Intraassay coefficient of variation was 5.0 percent. The dilution curve remained linear down to 1: 16. Recovery of IGF-I at the various standard concentrations to the plasma was 103 to 110 percent. The number of samples in each assay was 4 to 6 in both groups.

The Student $t$-test was used for statistical comparisons.

\section{Results}

The body weight of MSG-treated mice was less at 4 weeks of age and greater at 12 and 20 weeks of age than that of the controls. MSG-treated mice had decreased nasoanal and tail lengths at all ages studied (Table 1). We observed hardly any autotailmutilation in the MSG-treated mice. The Lee indices of MSG-treated mice surpassed those of the controls after 8 weeks of age. Plasma IRI levels were increased in MSG-treated mice on and after 8 weeks of age. There was no significant difference between the plasma T4 levels in MSG-treated mice and those in the controls at any age studied (Table 2). Plasma IGF-I levels in MSG-treated mice were decreased at all ages studied (Fig. 1).

\section{Discussion}

These results showed that plasma IGF-I levels of MSG-treated mice were already decreased at 1 week of age, and this remained unchanged up to 20 weeks of age. Although it was reported that the serum concentration of IGF-I was reduced by $55 \%$ at 14 weeks of age in MSG-treated rats [6], our present study revealed that a decrease in plasma IGF-I levels occurred as early as 1 week of age,

Table 2. Plasma IRI and T4 in MSG-treated mice and controls

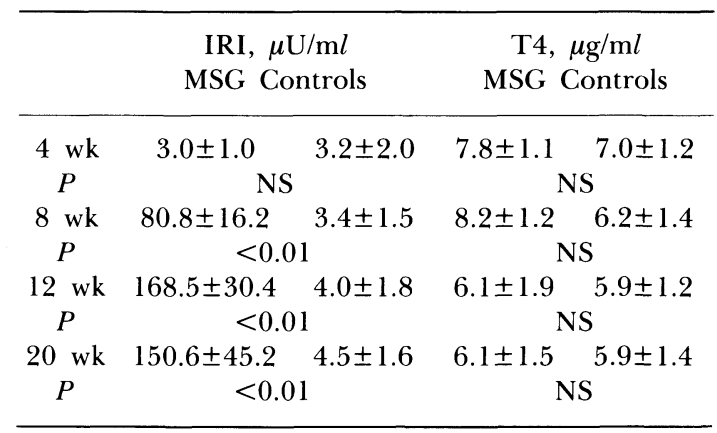

Values are the mean $\pm \operatorname{SD}(\mathrm{N}=4,5)$.

Table 1. Morphological characteristics of MSG-treated mice

\begin{tabular}{|c|c|c|c|c|c|c|c|c|}
\hline & \multicolumn{2}{|c|}{ Weight, $g$} & \multicolumn{2}{|c|}{$\begin{array}{c}\text { Nasoanal length, } \\
\mathrm{cm}\end{array}$} & \multicolumn{2}{|c|}{ Lee index } & \multicolumn{2}{|c|}{ Tail length } \\
\hline & MSG & Controls & MSG & Controls & MSG & Controls & MSG & Controls \\
\hline $4 \mathrm{wk}$ & $17.6 \pm 3.5$ & $27.3 \pm 3.0$ & $7.5 \pm 0.5$ & $8.7 \pm 0.4$ & $346.8 \pm 11.3$ & $346.1 \pm 12.4$ & $6.7 \pm 0.4$ & $7.9 \pm 0.7$ \\
\hline$P$ & \multicolumn{2}{|c|}{$<0.01$} & \multicolumn{2}{|c|}{$<0.01$} & \multicolumn{2}{|c|}{ NS } & \multicolumn{2}{|c|}{$<0.01$} \\
\hline $8 \mathrm{wk}$ & $39.7 \pm 3.8$ & $39.7 \pm 3.1$ & $9.1 \pm 0.4$ & $10.1 \pm 0.4$ & $373.5 \pm 18.7$ & $336.4 \pm 9.2$ & $8.3 \pm 0.6$ & $9.5 \pm 0.3$ \\
\hline$P$ & \multicolumn{2}{|c|}{ NS } & \multicolumn{2}{|c|}{$<0.01$} & \multicolumn{2}{|c|}{$<0.01$} & \multicolumn{2}{|c|}{$<0.01$} \\
\hline $12 \mathrm{wk}$ & $53.3 \pm 6.0$ & $43.9 \pm 2.9$ & $9.8 \pm 0.4$ & $10.4 \pm 0.3$ & $383.4 \pm 12.1$ & $339.4 \pm 9.9$ & $8.5 \pm 0.6$ & $9.7 \pm 0.5$ \\
\hline$P$ & \multicolumn{2}{|c|}{$<0.01$} & \multicolumn{2}{|c|}{$<0.01$} & \multicolumn{2}{|c|}{$<0.01$} & \multicolumn{2}{|c|}{$<0.01$} \\
\hline $20 \mathrm{wk}$ & $62.1 \pm 5.7$ & $52.1 \pm 7.1$ & $10.2 \pm 0.5$ & $10.7 \pm 0.3$ & $388.3 \pm 15.9$ & $348.8 \pm 13.8$ & $9.1 \pm 0.4$ & $10.0 \pm 0.3$ \\
\hline$P$ & \multicolumn{2}{|c|}{$<0.01$} & \multicolumn{2}{|c|}{$<0.01$} & \multicolumn{2}{|c|}{$<0.01$} & \multicolumn{2}{|c|}{$<0.01$} \\
\hline
\end{tabular}

Values are the mean $\pm \mathrm{SD}(\mathrm{N}=18-22)$

Lee index $=\frac{\sqrt[3]{\text { weight, } \mathrm{g}}}{\text { nasoanal length, } \mathrm{cm}} \times 10^{3}$ 


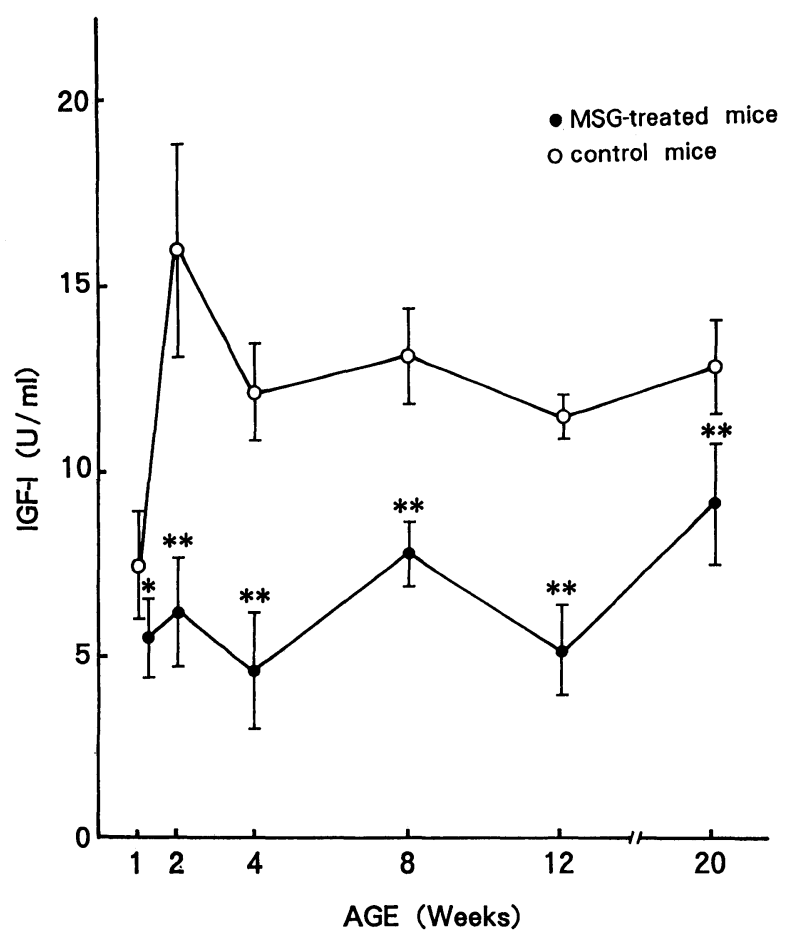

Fig. 1. Plasma IGF-1 levels in MSG-treated mice and controls. Data are shown as the mean \pm SD for $5-6$ animals per group. ${ }^{*}, P<0.05$; ${ }^{*}, P<0.01$.

soon after MSG injections. This decrease in plasma IGF-I may be explained by a putative reduction in $\mathrm{GH}$ secretion. There are several reports stating that the serum level of GH was reduced [6-10] in MSG-treated rats and that the amount of GH in the pituitary gland was decreased at 60,150 and 420 days of age in MSG-treated mice [11], as well as in MSG-treated rats [6, 12]. In one report, it was shown that acute administration of MSG to adult rats caused an immediate, long-lasting suppression of rhythmic GH secretion [8]. The reduced GH secretion seems to be due to the loss of $\mathrm{GH}$ releasing factor (GRF), because it is reported the MSG-injection into rodents during neonatal period results in GRF deficiency in the hypothalamic arcuate nucleus and median eminence $[6,11]$. In addition, it was shown histologically that MSG injections into neonatal animals produced neuronal loss in the arcuate nucleus $[2,8]$ and specific depletion of immunoreactive GRF in the median eminence [13].

Unlike human subjects, in whom the plasma level of IGF-I rises gradually throughout early childhood and reaches a peak in midpuberty [5], the plasma level of IGF-I in mice seems to have two peaks which occur during the suckling period and puberty. This suggests that the increase in plasma IGF-I is an important factor in growth during the neonatal period in mice. The plasma IGF-I level is known to be influenced by the nutritional state [14]. Apart from control mice, MSG-treated mice showed a slight increase in plasma IGF-I at 20 weeks of age in our experiments. This might have resulted from the prolonged obesity of MSG-treated mice. Indeed, it was reported that in human subjects serum IGF-I was increased in the obese more than in adult controls [15]. It is possible that reduced IGF-I may be attributed to the reduction of food intake in MSG-treated mice [16]. However it is unlikely because the reduction of food intake is slight and persists even after the development of obesity [16].

On the other hand, there was no significant difference between MSG-treated mice and controls in plasma T4. It was previously shown that serum T4 was not significantly different in male MSG-treated mice from that in controls at 18 weeks of age [17]. Furthermore, it was reported that there was no significant difference between female MSG-treated mice and controls in the level of plasma triiodothyronine (T3), in which MSG injections were done in the same way as ours [18]. Though it was reported that serum T4 [7], T3 and free $\mathrm{T} 4$ index [10] were significantly reduced to below control values in female MSG-treated rats and in an early report there was no significant difference between male MSG-treated rats and controls in the levels of serum T4 [7]. It is therefore suggested that thyroid function does not have a significant effect on the growth of MSGtreated animals.

The hyperinsulinemia noted in MSG-treated mice has already been reported both in fasting and ad libitum-fed states at 10 weeks of age [19]. Hyperinsulinemia is considered to be due to a lesion of the ventromedial nucleus which is observed in MSG-treated mice [2]. Hyperinsulinemia is not considered to result from insulin resistance in MSG-treated mice, because it occurs before the development of obesity at 8 weeks of age, when the plasma glucose level is in the normal range [20]. It is thought that the lesion of the ventromedial nucleus results in stimulation of the vagus nerve and increased sensitivity of the $\beta$ receptor in the $\beta$ cells of the islet, thus contributing to the development of hyperinsulinemia [21]. It 
should be noted that the development of hyperinsulinemia and obesity occurred simultaneously at 8 weeks of age. This suggests that there is a causal relationship between hyperinsulinemia and obesity.

In conclusion, it is suggested that decreased plasma IGF-I contributes to the rapid and sustained development of stunted growth and hyperinsulinemia to the later development of the obesity found in MSG-treated mice. Thyroid function may not play a role in the development of stunted growth and obesity, although the lack of agreement among reports on the endocrinological functions of MSG animals might to be dependent on the schedule of injections of MSG, species and the sex of the animals. It remains unanswered why the development of hyperinsulinemia lags behind the decrease in plasma IGF-I in spite of simultaneous injury to the hypothalamic arcuate and ventromedial nuclei caused by MSG injections.

\section{References}

1. Olney JW (1969) Brain lesions, obesity, and other disturbances in mice treated with monosodium glutamate. Science 164: 719-721.

2. Tanaka K, Shimada M, Nakao K, Kusunoki T (1978) Hypothalamic lesion induced by injection of monosodium glutamate in suckling period and subsequent development of obesity. Exp Neurol 62: 191-199.

3. Hashigami Y (1989) Effects of neonatal administration of monosodium glutamate on four neuropeptide concentrations in the rat brain. Folia Endocrinol Japon 65: 79-90 (In Japanese).

4. Bernardis LL, Patterson BD (1968) Correlation between 'Lee index' and carcase fat content in weanling and adult female rats with hypothalamic lesions. J Endocr 40: 527-528.

5. Suwa S, Katsumata N, Maesaka H, Tokuhiro E, Yokoya S (1988) Serum insulin-like growth factor I (somatomedid-C) level in normal subjects from infancy to adulthood, pituitary dwarfs and normal variant short stature. Endocrinol Japon 35: 857-864.

6. Maiter D, Underwood LE, Martin JB, Koenig JI (1991) Neonatal treatment with monosodium glutamate: Effects of prolonged growth hormone $(\mathrm{GH})$-releasing hormone deficiency on pulsatile $\mathrm{GH}$ secretion and growth in female rats. Endocrinology 128: 1100-1106.

7. Bakke JL, Lawrence N, Bennett J, Robinson S, Bowers CY (1978) Late endocrine effects of administering monosodium glutamate to neonatal rats. Neuroendocrinology 26: 220-228.

8. Terry LS, Epelbaum J, Martin JB (1981) Monosodium glutamate: Acute and chronic effects on rhythmic growth hormone and prolactin secretion, and somatostatin in undisturbed male rat. Brain Research 217: 129-142.

9. Millard WJ, Martin JB, Audet J, Sagar SM, Martin JB (1982) Evidence that reduced growth hormone secretion observed in monosodium glutamatetreated rats is the result of a deficiency in growth hormone-releasing factor. Endocrinology 110: 540550 .
10. Nemeroff CB, Konkol RJ, Bissette G, Youngblood W, Martin JB, Brazeau P, Rone MS, Prange AJ, Breese GR, Kizer JS (1977) Analysis of the disruption in hypothalamic-pituitary regulation in rats treated neonatally with monosodium L-glutamate (MSG): Evidence for the involvement of tuberoinfundibular cholinergic and dopaminergic systems in neuroendocrine regulation. Endocrinology 101: 613-622.

11. Nagasawa H, Yanai R, Kikuyama S (1974) Irreversible inhibition of pituitary prolactin and growth hormone secretion and of mammary gland development in mice by monosodium glutamate administered neonatally. Acta Endocr 75: 249-259.

12. Redding TW, Schally AV, Arimura A, Wakabayashi I (1971) Effect of monosodium glutamate on some endocrine functions. Neuroendocrinology 8 : 245-255.

13. Bloch B, Ling N, Benoit R, Wehrenberg WB, Guillemin R (1984) Specific depletion of immunoreactive growth hormone-releasing factor by monosodium glutamate in rat median eminence. Nature 307: 272-273.

14. Unterman TG, Vasquez RM, Slas AJ, Martyn PA, Phillips LS (1985) Nutritional and somatomedin. VIII. Usefulness of somatomedin-C in nutritional assessment. Am J Med 78: 228-234.

15. Hochberg Z, Hertz P, Colin V, Shalom S, Yeshurun D, Youdim MBH, Amit T (1992) The distal axis of growth hormone $(\mathrm{GH})$ in nutritional disorders: GH-binding protein, insulin-like growth factor-I (IGF-I), and IGF-I receptors in obesity and anorexia nervosa. Metabolism 41: 106-112.

16. Inoue F (1985) Intestinal disaccharidases in monosodium L-glutamate treated obese mice. I. Developmental alteration in intestinal brush border enzyme activities. J Kyoto Pref Univ Med 94: 7-16.

17. Poon TY-K, Cameron DP (1978) Measurement of oxygen consumption and locomotor activity in monosodium glutamate-induced obesity. Am J Physiol 234: E532-534.

18. Yoshioka K, Yoshida T, Kondo M (1991) Reduced 
brown adipose tissue thermogenesis and metabolic rate in pre-obese mice treated with monosodiumL-glutamate. Endocrinol Japon 38: 75-79.

19. Cameron DP, Cutbush L, Opat F (1978) Effects of monosodium glutamate-induced obesity in mice on carbohydrate metabolism in insulin secretion. Clin Exp Pharmacol Physiol 5: 41-51.

20. Furukawa N (1981) Carbohydrate metabolism in monosodium L-glutamate-treated obese mice. I. Gluconeogenesis and glycolysis in liver. J Kyoto Pref Univ Med 90: 339-350 (In Japanese).

21. Inoue S, Mullen YS, Bray GA (1983) Hyperinsulinemia in rats with hypothalamic obesity: effects of autonomic drugs and glucose. Am J Physiol 245: R372-378. 